\title{
ENVIRONMENTAL CONSERVATION IN MILITARY TRAINING AREAS-SOURCE OF SPATIAL CONFLICTS?
}

\author{
TOMÁŠ SEIDL, PAVEL CHROMÝ \\ Department of Social Geography and Regional Development \\ Faculty of Science, Charles University in Prague \\ Albertov 6, 12843 Praha 2, Czech Republic \\ e-mail: tomas.seidl@centrum.cz chromy@natur.cuni.cz
}

\begin{abstract}
The aim of the paper is to provide the overview of the spatial development conflicts linked with the existence of Military training areas (MTA) in the regional system. Only several places in the Central European space can be called new wilderness. Above all these are the MTA. The environmental history of these spaces went through a deep reversion. Changes in their cultural, political as well as social-economic profile can be compared with the specific belt of the former Iron Curtain zones only. Last two decades were essential for the physical existence of the MTAs. Because of the weak local political power, social capital and wide public support, are most of the decommitted MTAs in a deep conceptual crisis. The presented study finds solutions based on a long lasting research.
\end{abstract}

Key words: military area, environmental values, decommittment, core-periphery, Czechia

\section{MILITARY TRAINING AREAS-INTRODUCTION AND RESEARCH CONTEXT}

The aim of the paper is to 1) contribute to the discussion of spatial polarization, spatial polarization mechanisms and causations of peripheral/marginal areas shaping; 2) document the spatial polarization in the case of MTA, discuss the marginalization process and the environmental capital in the development process; 3 ) analyse the agents of the development process, respectively vision conflict/the conflict among "protection" and exploitation. The study deals with the question whether the environmental conservation presents a source of spatial conflict in the process of MTA development in general. At the conclusion it finds the solution based on best practices seeking.

There are only several places in the Central European space which we can call the new wilderness. Above all these are the so called military training areas. 
The environmental history of these spaces went through a deep reversion. Changes in their cultural and political as well as social and economic profile can be compared with the specific belt of the former Iron Curtain zones only. No other areas except the core zones of the national parks and reserves are nowadays so rich on environmental values like the military polygons with a unique charm (see e.g. Pavlíčko 2000, Grulich 2007, Grulich, Vydrová 2004, Vydrová 2007). Their exceptionality consists in regime of the public entry and low population density. These factors mainly involve a rich occurrence of the endangered species and a low public pressure on the nature exploitation.

The European cultural space is being characterized by the intensive way of affecting the environment. The currently living society occupies a landscape which has been completely influenced by the human activity and also the genesis of the military training areas was dependent on several factors. Above all the anthropogenic evolution dynamics represents one of the most important roles. The majority of the European MTAs was demarcated in economic insignificant regions (Gazenbeek 2005) which epitomized peripheries at the time of the polygons creation. Those regions could be denominated as periphery by then. The second very important factor represents the population migration (either spontaneous or forced). In the case of the most Czech existing or decommitted MTAs were the forced migration hand in hand with the ideal geographic conditions a crucial impulse for dislocation generation. Fig. 1 illustrates the dislocation of the Czech MTAs with retrospective into the Cold War period. It is evident that the number of MTAs declines in the west-east gradient. The Czech Germans transfer after the WWII evocated the question how to turn the abandoned areas into advantage. The settlement system

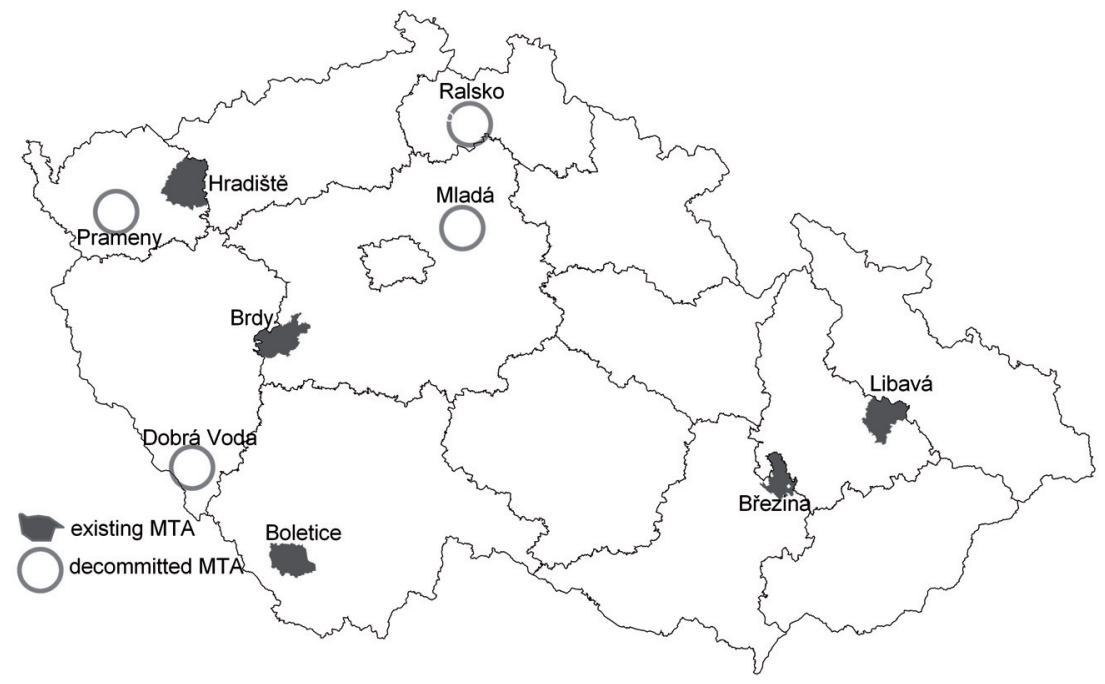

Figure 1. Czech military training areas dislocation, 2009

Source: own elaboration. 
evolution was due to population density hardly destabilized and the possibility of MTAs demarcation was one of the consequent solutions. Political conditions and the growing disability to establish relations between the East and the West lead into the total estrangement of the former cooperating nations in the Czech-German cultural area. The Iron Curtain genesis deepened the marginalization process of the Czech-German borderland (nowadays so idyllically called The Green Roof of the Central Europe). Despite of that all these circumstances provided superb conditions for the environment evolution, succession and recurrence of the endangered species like Lynx lynx, Tetrao urogallus, Crex crex, Cottus gobio, Margaritifera margaritifera, Maculinea species etc. and conditions for the natural evolution of the nature territories types.

\section{AGENTS OF THE REGIONAL DEVELOPMENT-THE CASE OF MTAS}

The above described processes are exemplary for the large scale polygons with special administration conditions and unique position in regional system. Besides there are spatially less significant small scale training polygons still being used in the entire Czech regional system. Or they has been as well as MTAs decommitted. The environmental values in these small scale polygons are as rich as in the case of the MTAs. In reference to the process of army professionalization in Czechia the area of both types of the militarily used land (Table 2) is currently being reduced. The issues of the usage of such decommitted/abandoned spaces are presently important due to endangered environmental values. Using the approaches to the applied research of the existing MTAs in Czechia we are currently able to define these spaces as the only marginal areas in the Czech regional system. According to Andreoli's approach of the continuum from cores till marginal zones on the opposite side of the polarised space (Andreoli 1994) we are on the basis of Leimgruber's structuring (Leimgruber in Jussila, Leimgruber, Majoral 1998) able to define the military marginal areas as geometrically determined marginal zones as well as economically and mainly socially determined. Conversely MTAs represent the inversion of ecologically determined marginal zones. Similarly it was already mentioned in connection with militarily used area in the case of Boletice MTA (for the details see also Seidl, Chromý 2009 or Seidl 2009) the problems of the marginal areas are more complicated and complex rather than the problems of the periphery and they should be solved by the external intervention (Chromý, Jančák 2005, Havlíček, Chromý 2001). Marginal area often does not have sufficient political support for changing the trend of the evolution. And because of the low population and settlement density in such areas the public interest is mainly affected by stakeholders and interested involved persons and special interest groups. The spatial polarisation theories discuss the role of the core in the regional system and regional development processes in general. It is evident that the power of the core is much stronger and the final incidence is more effective rather than the weak position of the peripheries. The historical and political 
processes in the case of the borderland regions in the territory of the former Iron Curtain zones influenced local social and human capital in a long term (Havlíček, Chromý, Jančák, Marada 2008). Especially the political changes after the end of WWII lead to intensification of the insulating border function (Hampl 2000). These processes like settlement decline (Kučera 2007) also lead in specific evolution processes, which spatial implication is still evident in social, cultural area, in the landscape etc. (Chromý 2000, Kuldová 2005).

It is evident that the physical barrier of the MTA existence is projected into the communal living. Experts as well as civilians are divided up to two almost implacable special interest groups in the issues of the military training areas existence and usage. The political background of the presented solutions is very obvious. We identify eight important agents involved in the spatial development / conflicts in the case of the MTAs (Fig. 2).

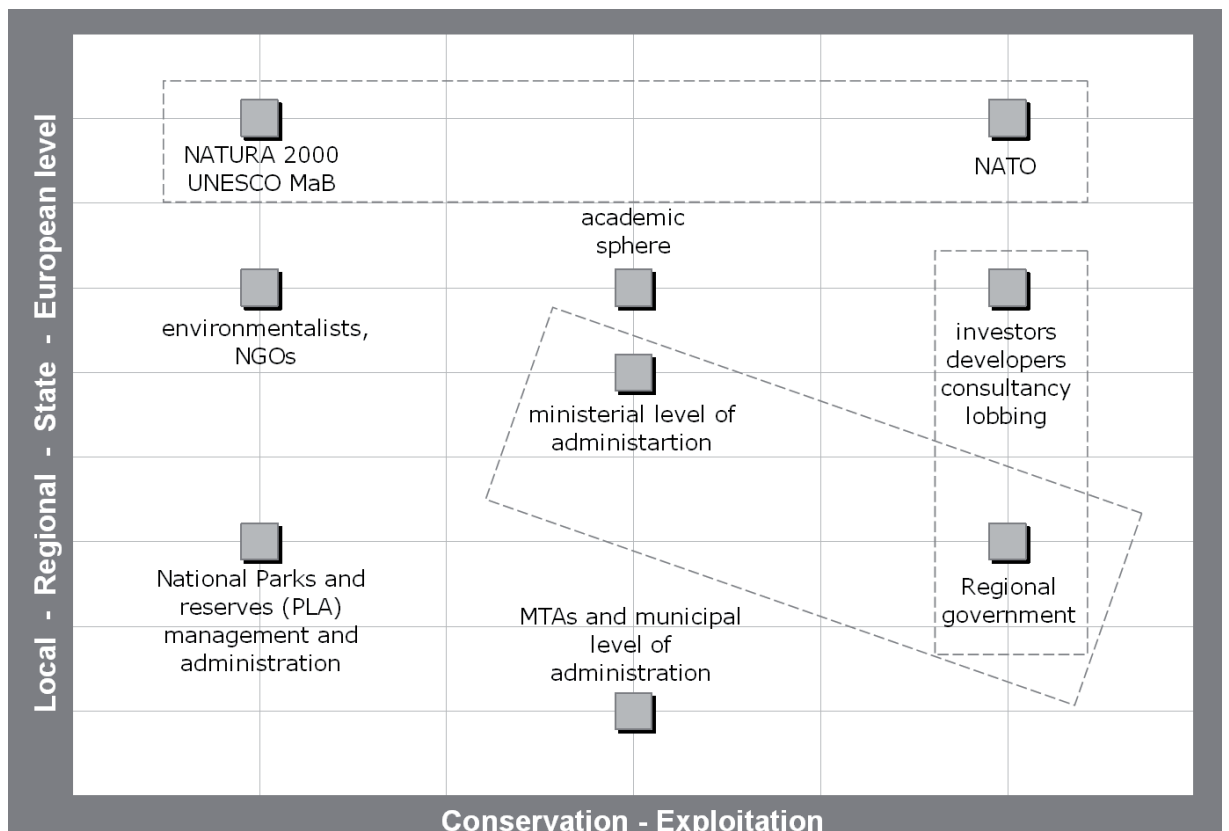

Figure 2. Agents involved in the spatial development / conflicts in the case of MTAs Source: own elaboration.

Comment: Dashed line indicates functional or firm structure.

The civic element is missing indeed in particular. In the case of MTA Boletice, which is discussed more precisely in the following part, we have detected the total absence of any subsumption of the public opinion in the conception discussion. As late as we presented the outcomes of the field survey realised in the inner space of the Boletice MTA in 2004 and on the different levels of administration in Boletice MTA surroundings (realised in 2007), there was no other reflection of the public opinion included into any relevant conception or investment project. The first intro- 
duction of our original research outcomes together with detailed situation analysis of the interested area was presented in the conception "Boletice-Study of Polyfunctional Use” (Zýval et al. 2005), (for details see also Seidl, 2007, 2009, Seidl, Chromý 2009).

\section{ENVIRONMENTAL PROTECTION CONTEXT-THE CASE STUDY OF MTA BOLETICE}

The environmental protection instruments constitute the important factors, which are essential in the process of affecting the future spatial and socio-economic development in the MTAs and their surroundings ${ }^{1}$. The main role executes the Natura 2000 concept. The identification and delimitation of Natura 2000 territories was based on scientific criteria. Mapping of habitat types and species territories was realized in each EU member state including the MTAs as well. Natura 2000 network in Czechia delimitates core natural zones with the necessary level of strict protection and is adopted in the Act No. 114/1992 Coll. on the Nature and Landscape Protection. The network incorporates two types of protection areas: Special Protection Areas (SPAs) and Sites of Community Importance (SCIs). Special Protection Areas are protected sites classified in accordance with Article 4 of the EC Directive on the conservation of wild birds (79/409/EEC). Sites of Community Importance are protected sites designated under the EC Directive on the conservation of natural habitats and of wild fauna and flora (92/43/EEC). Natura 2000 network covers $10,11 \%$ of the total Czech territory. It covers more than $68 \%$ of the whole MTA territories, which is a very important rate that influences a set of circumstances (Table 2). For an example SPAs were deliminated in five of nine former or existing large scale military polygons.

Figure documents the representation of SPAs in the Czech former or existing military training areas. The increased rate of natural protection in peripheries is generally known phenomenon and the Czech territory is an exemplar case (reserves concentration in outer geometrical periphery). Reaction to the post WWII historical and political evolution leads in gradual marginalisation of selected peripheral territories in the whole Europe. These selected territories characterized by low settlement density, unstable population and convenient geographical conditions were enclaved into strategic military polygons (especially in neighbourhood of the former Iron Curtain zones). The nature protection history in these territories did not replicate the natural process. Several factors caused the trend, which surpassed the environmentalists endeavour in major part of conventional reserves.

The extensive way of husbandry, succession processes acceleration, chemicals application absence in agriculture, pollution sources minimisation and above all almost total seclusion of large territories without the influence of permanent inhabitants lead into dynamic recurrence and natural values concentration. In the case of the former

\footnotetext{
1 The neighbouring municipalities of MTAs will be the first spatial units affected by any possible change in functional use of the military training areas (regardless of the chosen strategy of decommittment).
} 
Czechoslovakian or later Czech large scale MTAs it is also possible to speak about so called alternative protected areas/reserves (Petříček, Plesník 2007). Large scale MTAs often represent in the EU member states the most valuable example of habitats in the relevant country, especially in consequence to the condition of large area important for the dynamics of many species population (Gazenbeek 2005).

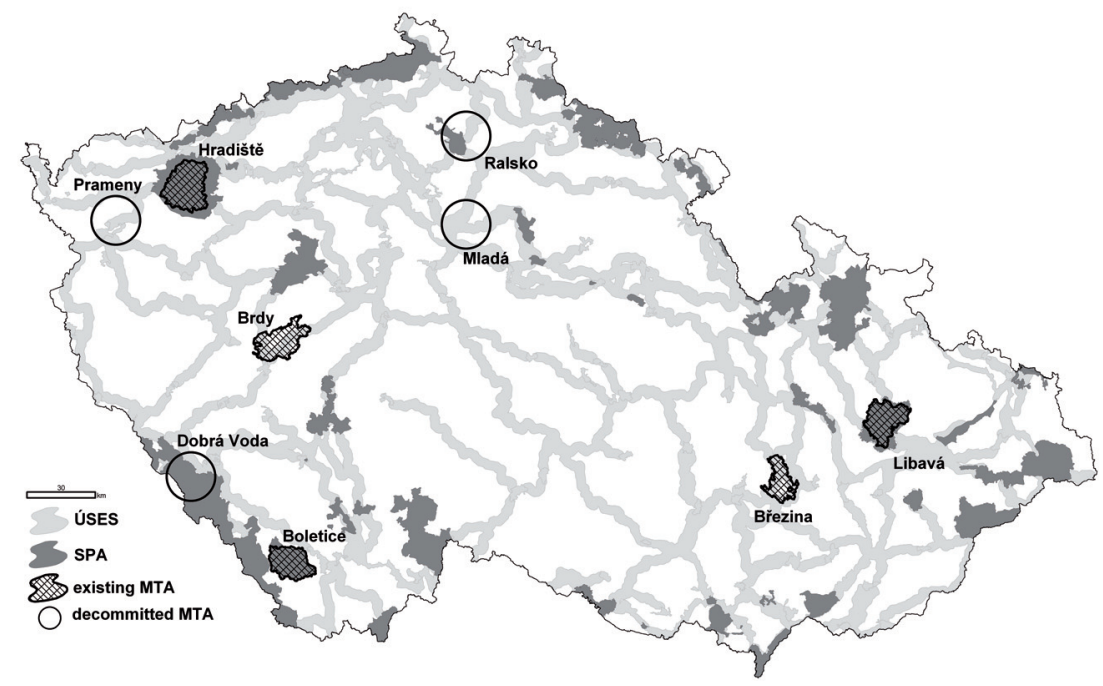

Figure 3. Natura 2000 network representation in the Czech MTAs (SPAs), 2009 Source: authors, adjusted on the basis of Czech Ministry of the Environment spatial data.

Comment: ÚSES represents the original Czech territorial system of ecological stability that incorporates biocentres and biocorridors on several hierarchical levels (the one presented in the map represents the national level). The concentration of such elements of the functioning system reflects biological values of the concrete territory.

Figure 4 documents the representation of SCIs in the Czech former or existing military training areas after the current enlargement in October 2009 declared by the government. It is evident that the spatial concentration of SCIs is in the case of military training areas significant and in comparision to the civilly used territories it covers large compact area of the military polygons. In case of small scale training polygons is the situation analogical. Small scale SCIs are often delimited in the former training polygons and Garrison training-grounds.

The elementary characteristics of Natura 2000 network is its location in total preservered territories or otherwise in territories with multifunctional use. MTAs rightfully figures among them. Natura 2000 network therefore composes significant areal rate in the existing or decommitted military areas of the EU. The network is here such frequent due to MTAs delimitation in economically insignificant territories, often unsuitable for agricultural growth. They already represented marginal zones in the time of their demarcation. Western European causation is divergent from the Czech or former East practices, but the resulting status after the decades of military use is very similar. The natural values dominate in all of them. 


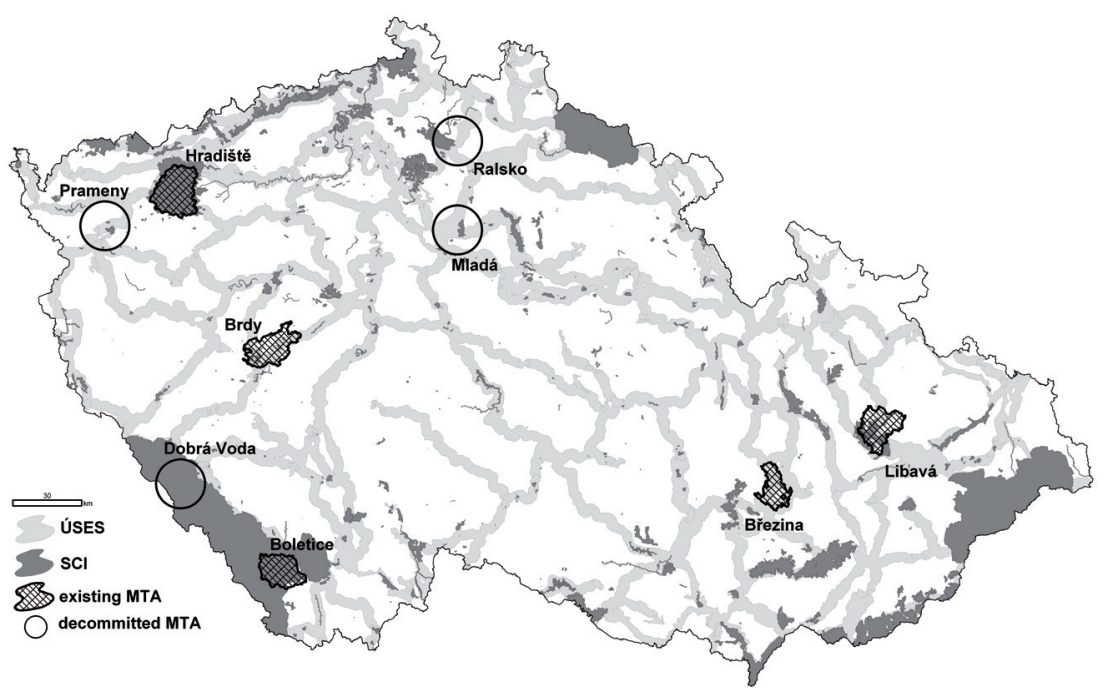

Figure 4. Natura 2000 network representation in the Czech MTAs (SCIs), 2009 Source: authors, adjusted on the basis of Czech Ministry of the Environment spatial data. Comment: ÚSES represents the original Czech territorial system of ecological stability that incorporates biocentres and biocorridors on several hierarchical levels (the one presented in the map represents the national level). The concentration of such elements of the functioning system reflects biological values of the concrete territory.

The time dimension estimation of the MTAs marginality lasting is dependent on the activity and the capability of the administration which should ensure the fulfilment of the Natura 2000 network fundamentals implementation. The role of Natura 2000 network faces to the growing pressures of the interest groups/networks of developers, political fractions and interested commercial domain involved persons.

\section{SPATIAL CONFLICTS}

Last two decades were essential for the physical existence of the MTAs in the Central and Eastern Europe. More than 10000 square kilometers of these polygons were abandoned (Table 1). Because of the weak local political power, local social capital and wide public support, are most of the decommitted MTAs in deep conceptual crisis. There are only few best practices in the process of conversion which could be followed. They are based on the cooperation between the environmental conservation and sound usage of the geographical potential. Also the cooperation of military and environmental sector of administration is beneficial. But of course the profit of the use of these spaces should be reflected in the state of local economy of the neighbouring municipalities and regions. The question is how to turn to the advantage the existence of the MTA for the public sector with- 
out any negative impact on its natural heritage? The necessary external methodical and financial intervention should be widely balanced and must reflect the expectations of the local inhabitants as well as it should include the principles of environmental protection.

Table 1. Essential area parameters of the military-strategic function surfaces and trends in the usage after the 1989 in selected West European countries compared to former Czechoslovakia successors

\begin{tabular}{|l|c|c|c|c|}
\hline & $\begin{array}{c}\text { Former } \\
\text { military-strategic } \\
\text { function area } \\
\left(\mathrm{km}^{2}\right)\end{array}$ & $\begin{array}{c}\text { Current } \\
\text { military-strategic } \\
\text { function area } \\
\left(\mathrm{km}^{2}\right)^{* *}\end{array}$ & $\begin{array}{c}\text { The rate of } \\
\text { the Natura 2000 } \\
\text { in the MSF area } \\
(\%)\end{array}$ & $\begin{array}{c}\text { The rate of } \\
\text { the military-strategic } \\
\text { function area to } \\
\text { the total area }(\%)\end{array}$ \\
\hline The Netherlands & 600 & 400 & 50 & 1 \\
\hline Belgium & $\cdot$ & 250 & 70 & 0,8 \\
\hline Denmark & $\cdot$ & 710 & 45 & 1,6 \\
\hline France & $\cdot$ & $\cdot$ & $\cdot$ & 0,5 \\
\hline Italy & $\cdot$ & $\cdot$ & $\cdot$ & 0,6 \\
\hline UK & 1774 & 1297 & 68 & 1 \\
\hline Czechia & 874 & $541^{*}$ & 39 & 1,1 \\
\hline Slovakia & 2648 & $\mathrm{x}$ & $\mathrm{x}$ & 2 \\
\hline Czechoslovakia &. & $\cdot$ & 6 & 1,6 \\
\hline
\end{tabular}

Source: adjusted on the basis of Gazenbeek (2005), Komár (1993) and information of Ministry of Defence of Slovakia.

Comment:

* - except MTA Javorina

** - Situation in the 2005-2007 period

MSF- military-strategic function

Table 1 displays selected characteristics typical for MTAs in the past two decades. The total militarily used area decreases both in the former Western and Eastern European sector. The rate of the Natura 2000 network in the militarily used area is both dominant. The total area of militarily used territories is in the former Eastern European countries much higher. An important role acts the ownership of the land. Compared to the former Western European countries there is still plenty of land owned by the state or land funds in the East. This was also an important fact, which played fundamental role in the Natura 2000 territories ratification process. The ratification mainly opposed to lobbing and special interested groups but not lawful owners.

Militarily used areas spatial reduction is dependent upon the process of army reorganisation and professionalisation. Table 2 displays the trend of spatial reduction but functional intensification in the case of training polygons usage in Czechia. Hence it follows that the importance of MTAs existence is not only declared but proclaimed. The growing pressure on the land usage especially in environmentally valuable territories focuses on the abandoned unowned land (even though the owner 
Table 2. Militarily used areas spatial reduction depending upon the Armed forces of the Czech Republic reorganisation

\begin{tabular}{|l|c|c|c|c|}
\hline & 1990 situation & 2008 situation & 2012 perspective & $\begin{array}{c}\text { Decommitted } \\
\text { area, 2008 }\left(\mathrm{km}^{2}\right)\end{array}$ \\
\hline Large-scale MTAs & 8 & 5 & 5 & 478 \\
\hline $\begin{array}{l}\text { Small-scale polygons } \\
\text { aside MTA }\end{array}$ & 66 & 5 & 3 & 60 \\
\hline $\begin{array}{l}\text { Garrison } \\
\text { training-ground }\end{array}$ & 86 & 13 & 11 & \\
\hline Total & $\mathrm{x}$ & $\mathrm{x}$ & $\mathrm{x}$ & 538 \\
\hline
\end{tabular}

Source: adjusted on the basis of Analýza existence vojenských újezdů MO ČR 2007.

Comment: The table expresses the spatial projection of the main Armed forces of the Czech Republic dislocation into the MTAs distance proximity.

is the government). The historical ownership is obvious and the historical land use can be documented. The attitude of the environmentalists officially represented by the ministerial level faces to valid opinion therefore.

In media currently promoted project of NATO Missile Defence which was aimed besides Poland to the Czech MTA Brdy is no more up-to-date. And as it was mentioned in the introduction part of the paper, the political background of any project is obvious. Due to forthcoming parliamentary elections in the 2010 we can expect a new wave of pressure on the Boletice MTA decommittment. The wave of "interest" in the very short period before the last parliamentary elections in 2006 lead in a common declaration including the real MTA demarcation change consequently (for more information see: Collective declaration of Ministry of Defence, Ministry of the Environment, Local Development Ministry, South Bohemian Region in re of civil use of the Boletice MTA, Prague, 2006).

In the case of Boletice MTA and on the bases of the outcomes of the realised applied research (e.g. Seidl 2009) we are able to declare the importance of the best practices utilisation. Anyone of the presented concepts based on hard tourism purpose usage of the militarily used territory reflects neither public opinion nor best practices realised at least in the Czech territory. The area of the southwest Czech borderland is since 1991 protected as National Park Šumava (proclaimed in 1991) and includes the most valuable natural heritage. Fig. 5 displays Natura 2000 representation and the location of the existing MTA Boletice and the decommitted area of the former MTA Dobrá Voda. MTA Dobrá Voda has been integrated into the originated National Park Šumava instantly after its proclamation. Even though, the military-strategic function was terminated up to 31. 12. 1992. The exceptionality of the former MTA Dobrá Voda consisted in its location right in the belt of the former Iron Curtain zones. The frontier belt of the Iron Curtain extended up to $15 \mathrm{~km}$ wide zone from the frontier line directly in the territory of the MTA. Similarity relation between the marginality of the MTAs and the so called "forbidden belt" of the frontier zone, which was totally unavailable, documents the position in 
the regional system. Both were sequestered from the system. MTA Dobrá Voda was automatically integrated into the structure of the new National park. In the territory of the former MTA Dobrá Voda does not dominate any other management than in the rest of the National park due to the Governmental Regulation and the regime of the Master plan of the region. Former MTA Dobrá Voda conversion process (the decommittment process) can be considered as an unique case, but in general it is possible to denominate it as a utility model. In opinion of the questioned specialists (applied research Seidl 2007) was conversion process in comparison to the other decommitted MTAs successful. The evolution of this territory is very dissimilar and it allows the effectivity evaluation of the realised proceedings, practices in the process of integration into the regional system. In addition to that there was a special methodological form of cooperation realised between the Czech and German specialists in the case of Dobrá Voda into the National park framework integration process. It is not easy to confirm whether existed civic or expert interest of decommittment was the most determining factor. But the important condition represented the geopolitical situation in the early nineties and geographical location analogous to proclaimed new National park Podyjí in the former frontier belt.

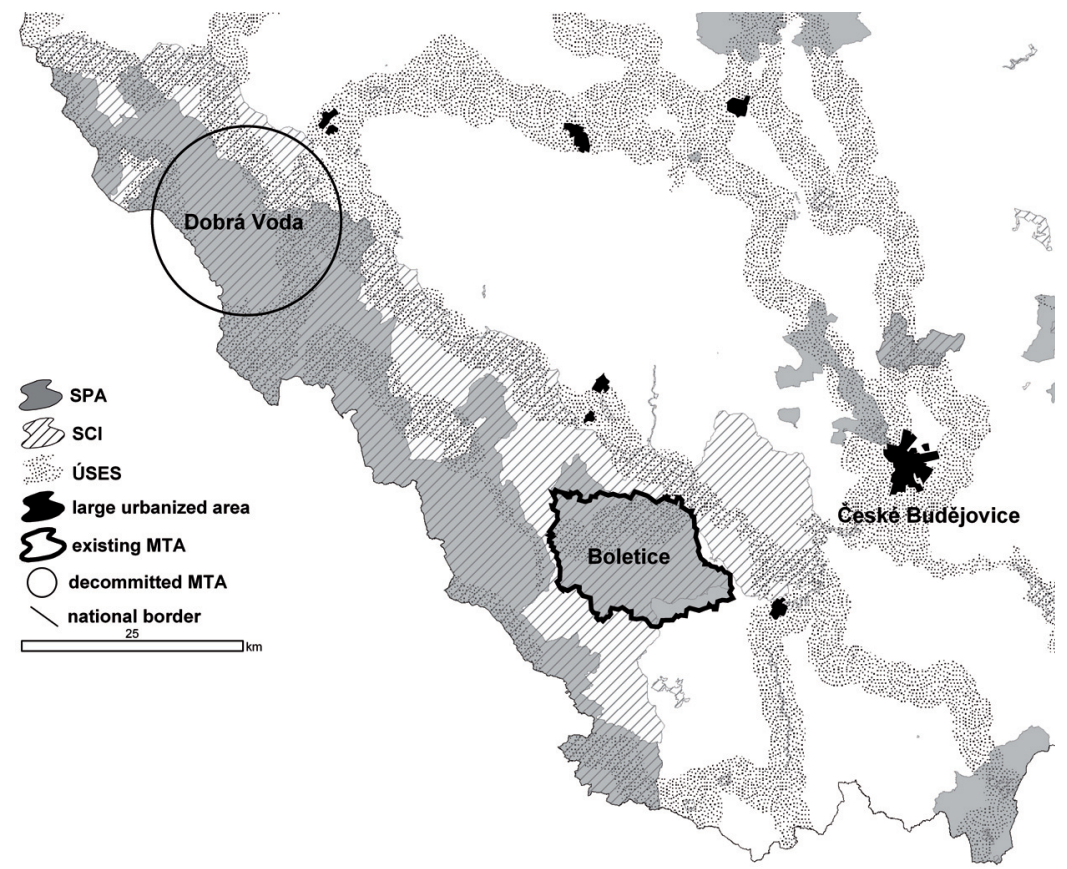

Figure 5. Natura 2000 network representation in the special interest area of Šumava borderland and the former or existing MTAs, (SPAs and SCIs), 2009

Source: authors, adjusted on the basis of Czech Ministry of the Environment spatial data. Comment: The Czech-German (Šumava) Borderland is protected on the level of national parks and reserves, Man and Biosphere Reserve, Natura 2000 network and compact territorial system of ecological stability. All the levels overlap and represent one of the most valuable compact environmental system in the central European space. 
In opinion of the National park and Protected landscape area Šumava administration it would be also possible to explore the opportunity of inspiration in the MTA Dobrá Voda decommittment process and in current usage problems of MTA Boletice. On the basis of our research outcomes the relevant stakeholders/agents of the regional development resigned in the methods of best practices seeking in the case of Boletice MTA conversion neither in the Czech territory nor in the European context.

\section{CONCLUSIONS}

The aim of the paper was to provide the overview of the spatial development conflicts linked with the existence of Military training areas (MTA) in the regional system. The presented paper finds solutions based on a long lasting research leading into the necessity of best practices seeking. Currently presented decommittment tendencies are in conflict with the fundamentals of environmental protection and Natura 2000 network implementation. EU member states are obliged to ensure and provide the permanent legislative protection in defined Special Protection Areas and Sites of Community Importance. There is almost no cohesion between the environmental aspects and currently presented developing projects.

It is essential to introduce subject and productive discussion among all the important regional development agents in the case of the alternative protected areas/reserves-MTAs. It is also essential to search for ecologically reasonable and compromise solution for the civic activities in the MTAs development. It is fundamental to take into account the impact of any concept on the subject of protection of the really affected Natura 2000 territory. The same should be reflected in the subsequent project phases. For Natura 2000 territories are suitable and acceptable sound forms of tourism in general (EC-Environment DG, 2001). Status worsening in the subject of protection is illegitimate. Missing best practicies references should be replaced by the model case of MTA Dobrá Voda decommittment or analogous processes realized mainly in the Western European countries. The solution should be searched in cooperation crosswise the administration levels and also in cooperation with the local institutions, special interest groups and local inhabitants in particular.

\section{ACKNOWLEDGEMENT}

This paper is the result of research findings sponsored by a grant project GAUK no. 58610 "Spatial Development Problems of the Former and Existing Military Used Areas". 


\section{REFERENCES}

Analýza existence vojenských újezdi̊ z hlediska porovnání potřeb armády a stanovených ekonomických kritérii, aktualizace materiálu k 1. březnu 2007, (2007), Ministerstvo obrany České republiky, Praha.

Andreoli, M.(1994), Development and marginalization in Liguria region, in: Chang-Yi, D. Ch. (eds.) Marginality and development issues in marginal regions. Proceedings of Study Group on Development Issues in Marginal Regions, IGU, Taipei, 41-60.

Collective declaration of Ministry of Defence, Ministry of the Environment, Local Development Ministry, South Bohemian Region in re of civil use of the Boletice MTA, Prague. 2006 [online]. 2007 [cit. 2007-10-20]. Accessible < http://www.krajjihocesky.cz/>

Gazenbeek, A. (2005), LIFE, Natura 2000 and the military, European Commision, Environment DG, Luxembourg.

Grulich, V. (2007), Flóra a vegetace Vojenského újezdu Boletice, in: Petříček, V. and Kuchařová, P., Ochrana př́rody a krajiny ve vojenských újezdech, AOPK ČR, Praha, 93-114.

Grulich, V. and Vydrová, A. (2004), Natura 2000 ve vojenských výcvikových prostorech—př́klad VVP Boletice, Ochrana přirody, 59 (7), 195-200.

Havlíček, T. and Chromý, P. (2001), Příspěvek k teorii polarizovaného vývoje území se zaměřením na periferní oblasti, Geografie-Sborník ČGS, 106 (1), 1-11.

Havliček, T., Chromý, P., Jančák, V. and Marada, M. (2008), Innere und äußere Peripherie am Beispiel Tschechiens. Mitteilungen der Österreichischen Geographischen Gesellschaft, 150, 299-316.

Hampl, M. (2000), Pohraniční regiony České republiky: současné tendence rozvojové diferenciace, Geografie-Sborník ČGS, 105 (1), 241-252.

Chromý, P. (2000), Historickogeografické aspekty vymezování pohraničí a jeho geografické analýzy, Geografie-Sborník ČGS, 105 (1), 63-76.

Chromý, P. and Jančák, V. (2005), Periferní oblasti Česka jako jeden z pólů polarizovaného prostoru, Životné prostredie, 34 (2), 106-108.

Jančák, V., Havlíček, T., Chromý, P. and Marada, M. (2008), Regional Differentiation of Selected Conditions for the Development of Human and Social Capital in Czechia, Geografie-Sborník ČGS, 113 (3), 269-284.

Jussila, H., Leimgruber, W. and Majoral, R. (eds.) (1998), Perceptions of marginality: theoretical issues and regional perceptions of marginality in geographical space, Ashgate, Aldershot.

Komár, A. (1993), Vojenský újezd Hradiště, Sborník ČGS, 98 (2), 75-86.

Kučera, Z. (2007), Zanikání sídel v pohraničí Čech po roce 1945—základní analýza, Historická geografie, 34, 317-334.

Kuldová, S. (2005), Příspěvek ke kulturněgeografickému výzkumu: možnosti hodnocení kulturních aspektů pomocí statistických metod, Geografie-Sborník ČGS, 110 (4), 300-314. 
Pavličko, A. (2000), Vojenský výcvikový prostor Boletice. Ochrana př́rody a krajiny v souvislosti s významnými druhy. Zlatá stezka, 7, Sborník Prachatického muzea, Prachatice, 283-323.

Petříček, V and Plesník, J. (2007), Tanky a mateřídouška-10 let poté, in: Petříček, V. and Kuchařová, P., Ochrana prírody a krajiny ve vojenských újezdech, AOPK ČR, Praha, 73-84.

Seidl, T. (2007), Geografický potenciál regionu Boletice, in: Petříček, V. and Kuchařová, P., Ochrana př́rody a krajiny ve vojenských újezdech, AOPK ČR, Praha, 85-92.

Seidl, T. (2009), Military Training Area Boletice-The case of marginal region in the Czech regional system, Acta Universitatis Carolinae-Geographica, 2. (in print).

Seidl, T. and Chromý, P. (2009), Turismus v alternativních chránéných územích-koncentrovaná exploatace nebo šetrné formy?, in: Dobrá praxe v udržitelnosti cestovního ruchu, Gaudeamus, Hradec Králové, 50-57.

Sustainable tourism and Natura 2000, Guideline, initiative and best practices in Europe, European Commision, Environment DG, Luxemburg 2001.

Vydrová, A. (2007), Botanicky cennélokality ve Vojenském újezdu Boletice, in: Petříček, V. and Kuchařová, P., Ochrana přrrody a krajiny ve vojenských újezdech, AOPK ČR, Praha, 115-126.

Zýval, V. et al. (2005), Vojenský újezd Boletice—studie polyfunkčního využití, Geovision s.r.o., Praha. 
http://rcin.org.pl 